\title{
STATUS OF THE HUMORAL LINK OF IMMUNITY AT EXPERIMENTAL PERITONITIS ON THE BACKGROUND OF DIABETES MELLITUS
}

Introduction. The combined course of acute peritonitis and diabetes increasingly leads to the development of secondary immunodeficiencies, which contribute to an increase in the percentage of postoperative complications and fatalities, the emergence of complexity of treatment and diagnosis.

The aim of the study - to learn the peculiarities of humoral link of the immune response in the organism of experimental animals during simulated acute common peritonitis on the background of diabetes mellitus compared with animals with experimental acute peritonitis alone.

Reserch Methods. 56 white rats were used in this work. Diabetes mellitus was modeled by intraperitoneal administration of Srethosotocin from "Sigma" firm with the rate of $7 \mathrm{mg}$ per $100 \mathrm{~g}$ of animal mass, acute peritonitis - insertion of $0.5 \mathrm{ml}$ of $10 \%$ of the captured fecal suspension into the abdominal cavity of the animals. The concentration of immunoglobulins in serum was determined. Observation time points: 1, 3, and 7 days from the beginning of the peritonitis modeling.

Results and Discussion. Analyzing the results of studies, it can be stated that there were observed directed changes in the concentration of immunoglobulins in blood serum of rats of different groups. Thus, on the first day after simulating acute common peritonitis on the background of diabetes, the level of Ig G decreased by 1.5 times, $\lg M-$ by 1.3 times and $\lg A-$ by 1.4 times $(p<0.05)$. On the seventh day of the experiment, levels of all classes of immunoglobulins were statistically significantly lower than those of the group with acute common peritonitis: Ig G level was lower by $21 \%$, Ig M and Ig A were lower by $17 \%$ and $56 \%$ respectively $(p<0.05)$. The results of our studies indicate that the presence of diabetes in acute general peritonitis leads to a decrease in the resistance of the humoral level of the immune system with antigenic stimulation and secondary immunodeficiency states.

Conclusions. In animals with acute peritonitis, protective mechanisms of the humoral immunity level are substantially reduced on the background of diabetes, which is confirmed by statistically significantly lower levels of immunoglobulins of classes A, M, G compared to a group of animals with a pattern of acute peritonitis. The revealed functional impairment of humoral immunity indicates an appreciable weakening of the organism's protection factors in acute peritonitis on the background of diabetes mellitus with the development of secondary immunodeficiency.

KEY WORDS: acute peritonitis; diabetes mellitus; humoral immunity; immunoglobulins.

INTRODUCTION. Peritonitis remains one of the most frequent complications of surgical diseases of the abdominal cavity [1, 2]. According to several studies, during severe forms of disseminated purulent peritonitis, the mortality reaches 50-80 \% [3-5]. This high mortality is due to the fact that peritonitis occurs on the background of already existing pathological changes caused by a comorbid state, the peculiarity of which is the absence of clear boundaries, the rapid spread of the pathological process in the abdominal cavity, the complexity of the diagnosis, etc. All this complicates the course of the acute general peritonitis (AGP) and indicates the need for further improvement of diagnostic methods and treatment of this pathological process.

(C) I. Ya. Dzyubanovsky, B. M. Vervega, S. R. Pidruchna, N. A. Melnyk, A. M. Prodan, 2019.
Treatment of peritonitis requires a multi-faceted approach. The severity of the course of peritonitis depends on the adequacy of the immune response. Correct immune response and sufficient reserves of body compensation contribute to the localization of the inflammatory site. Immune deficiency predisposes an unfavorable course of peritonitis, and it is characterized as a secondary acquired immunodeficiency state, which causes complications, sepsis and death of patients [6, 7].

In addition, one component of modern complex treatment of peritonitis, which is not included in the standards of treatment, is immunocorrection. Today, immunotherapy uses drugs, which include a complex of immunoglobulins (lg) of the main classes A, M, G (Ig A, Ig M, Ig G). However, the research on this topic suggests that these drugs should be 
used from the pathogenetic point of view, in a timely manner, during the phase of the first manifestations of symptoms of peritonitis and organ damage, and their later use as "therapy of despair" is pathogenetically and economically unjustified and ineffective measure [8].

At the same time, diabetes continues to be the most common endocrine pathology with a steady upward trend. Along with oncological and cardiovascular diseases, diabetes is one of the most common causes of disability and mortality in patients [9]. Over the past ten years, the prevalence of diabetes in Ukraine increased by 1.5 times and estimated at one million patients. Undoubtedly, nowadays it is considered that the condition of diabetes is a high risk factor for developing immunodeficiency states with purulent-inflammatory and necrotic processes. Despite the fact that in recent years some progress made in the study of the pathogenesis of the AGP and diabetes, however, until now, the role of the immune link of immunity with combined pathology was not fully understood [10].

The aim of the study - to learn the features of the humoral link of the immune response in the organism of experimental animals in the modeled AGP on the background of diabetes comparing to animals with experimental peritonitis alone.

RESEARCH METHODS. Experiments were performed at Central Research Laboratory of I. Horbachevsky Ternopil State Medical University (Certificate of Attestation No. 000478 dated 17.12.2007). The experiment used 56 white rats, which were divided into three groups: the main group - 24 animals with a simulated AGP on the background of diabetes: a comparison group -24 animals with simulated peritonitis alone; the control group consisted of 8 intact animals, which were kept under standard vivarium conditions. All comparable animal groups were of the same weight, gender, and age.

Experimental diabetes was artificially developed by intraperitoneal administration of streptozotocin on an empty stomach in a dose of $60 \mathrm{mg} / \mathrm{kg}$ (acquired from "Sigma" Company, which was dissolved in buffer sodium citrate solution $\mathrm{pH} 4.5$ ). The study of glucose content was carried out using the glucose oxidase method at 9:00 a.m., under conditions of free access of experimental animals to food and water during the night time period. During the entire observation period, rats received insulins ( $0-2$ units, subcutaneously two to five times a week).

Two weeks after the administration of streptosotocin, the venous blood of rats drown from the tail vein, was analyzed, and the glucose content was determined. In the subsequent studies, only those rats with glucose contents of more than $300 \mathrm{mg} / \mathrm{L}$ were used. Animals of the control group were subcutaneously administered sterile $0.9 \%$ sodium chloride solution instead of streptozotocin [11].

The influence of the diabetes on the course of the AGP was studied on the model suggested by Lazarenko et al. This model, regarding etiological factors, clinical manifestations, and phase transitions, is close to the similar process in human. On the $14^{\text {th }}$ day after administration of streptotrophin in the animals of the appropriate group, we injected $10 \%$ of the fecal suspension into the cranial cavity of the examined rats at a dose of $0.5 \mathrm{ml}$ per $100 \mathrm{~g}$ of body weight. Rats of the comparative group received only hypodermic administration of fecal suspension. Fecal suspension were prepared by mixing saline isotonic solution and feces from the intestine of 2-3 intact animals, then double-filtered through a double layer of gauze. The resulting slurry was introduced not later than 20 minutes after cooking introduce intact rats by puncture method. In order to avoid damage of internal organs when introducing fecal suspension into the abdominal cavity, the animals were held upright, caudal end up $[12,13]$.

The time points for observations were $1^{\text {st }}$, 3rd and $7^{\text {th }}$ days from the beginning of peritonitis modeling. To conduct research, we used whole blood and serum of blood, as well as liver homogenate.

This experimental study was conducted with observance of general rules and provisions of the European Convention on Protection of vertebrate animals used for research and others scientific goals (Strasbourg, 1986), General Ethical Principles experiments on animals (Kyiv, 2001) and the Law of Ukraine "On Protection of Animals from Cruel Behavior" (2006).

To characterize the functional state of humoral immunity the serum Ig concentrations of the main classes (M, G, A) were determined. The determination of $\mathrm{Ig}$ in serum was carried out by radial immunodiffusion globulin method according to G. Mancini et al. (1965), the principle of which is based on interaction of antigen of the test serum and antibody (antiserum to lg). The method is based on the procedure when samples of investigated serums are introduced into the wells of agar, which have antibodies to $\lg G, \lg A, \lg M$ (standard monospecific serum against human Ig). Immunoglobulins that diffuse into agar, during the interaction with the corresponding antibodies, form the rings of the precipitate, and their size depends on the number of serum Ig of a particular class. Results were evaluated graphically. The diameter of the obtained rings of precipitation was compared against standards. Using the points obtained with standards, we built a standard curve. Concentration 
that corresponds to the samples can be evaluated, by measuring the diameter of their rings and comparing it to the calibration curve. This method is sensitive and allows the researcher to determine concentrations of up to $0.003 \mathrm{~g} / \mathrm{L}$ of $\lg$ [14].

Statistical analysis of data was carried out using Excel and STATISTICA software, using parametric and nonparametric methods for evaluating the obtained data. For all indicators, we calculated the mean arithmetic mean (M), its dispersion and mean errors $(m)$. The reliability of the difference between independent quantitative values were determined with normal distribution for Student's t-criterion, in other cases - by Mann - Whitney's U-criterion the differences were considered to be significant at $\mathrm{p}<0.05$.

RESULTS AND DISCUSSION. Analyzing the results of the research of humoral immunity during the AGP a statistically significant increase in the concentration of immunoglobulins was noted compared to a group of intact animals. Increase of $\lg \mathrm{G}$ level in on day 1 from the moment of peritonitis modeling was $147 \%$, as for $\lg M-128 \%$, and $\lg A-138 \%$, comparing to corresponding values in rats without pathology (Table 1). Hyperproduction of immunoglobulins on the first day of the pathological process indicated an excess of toxins and antigens during AGP. In the following days, the concentration of immunoglobulins gradually decreased all the way to the $7^{\text {th }}$ day and was valued at to $92 \%$ comparing to the value of intact animals. At the same time, the concentration of $\lg \mathrm{M}$ and $\lg$ increased by the $3^{\text {rd }}$ day of observation and was, respectively, $169 \%$ and $145 \%$ of the levels of rats without simulated pathology. In the following days, the values were somewhat reduced on the $7^{\text {th }}$ day and the concentration of $\lg M$ was $140 \%$, and $\lg A,-128 \%$, comparing to the norm (healthy animals). Increase of the concentrations of $\lg M$ and $\lg A$ can be explained by the fact that they are immunoglobulins of acute phase of inflammation and are not enough specific for localization of antigenic load and effective completion of inflammation, but for insufficient level, lg G may partially compensate for their functions.

As for the model of the AGP on the background of diabetes, we noted a decrease in the level immunoglobulins of all classes starting even on the $1^{\text {st }}$ day of the pathological course of the process. Thus, Ig $G$ and $\lg M$ values were 1.5 times and 1.3 times less as those calculated in animals without a simulated pathology, and Ig A was lower by 1.4 times (Table 2). For 3 days in animals with simulated AGP on the background of diabetes the Ig G dropped to $89 \%$, while the Ig M level was $96 \%$,

Table 1 - Concentration of immunoglobulins in blood serum of rats with AGP (M $\pm m)$

\begin{tabular}{|c|c|c|c|c|}
\hline \multirow{2}{*}{ Number of types } & \multicolumn{4}{|c|}{ Groups of experimental animals } \\
\cline { 2 - 5 } & \multirow{2}{*}{$\begin{array}{c}\text { control } \\
(\mathrm{n}=8)\end{array}$} & \multicolumn{2}{|c|}{ animals with acute peritonitis $(\mathrm{n}=24)$} \\
\cline { 2 - 5 } & $3.61 \pm 0.05$ & $5.31 \pm 0.09^{\#}$ & 3 day $(\mathrm{n}=8)$ & 7 day $(\mathrm{n}=8)$ \\
\hline $\lg \mathrm{G}$ & $2.73 \pm 0.08$ & $3.50 \pm 0.14^{\#}$ & $4.61 \pm 0.16^{\#}$ & $3.31 \pm 0.16_{\#}$ \\
\hline $\lg \mathrm{M}$ & $1.73 \pm 0.02$ & $2.38 \pm 0.08^{\#}$ & $2.50 \pm 0.07^{\#}$ & $2.83 \pm 0.04^{\#}$ \\
\hline $\lg \mathrm{A}$ & $\mathrm{n}$ &
\end{tabular}

Note. ${ }^{\#-}$ is the authenticity of the difference between such independent values of intact groups.

Table 2 - Concentration of immunoglobulins in blood serum of rats with AGP on the background of diabetes ( $M \pm m)$

\begin{tabular}{|c|c|c|c|c|}
\hline \multirow{3}{*}{$\begin{array}{l}\text { Number } \\
\text { of types }\end{array}$} & \multicolumn{4}{|c|}{ Groups of experimental animals } \\
\hline & \multirow{2}{*}{$\begin{array}{c}\text { control } \\
(n=8)\end{array}$} & \multicolumn{3}{|c|}{ animals with agp on the background of diabetes $(n=24)$} \\
\hline & & 1 day $(n=8)$ & 3 day $(n=8)$ & 7 day $(n=8)$ \\
\hline $\lg G$ & $3.61 \pm 0.05$ & $\begin{array}{c}3.31 \pm 0.07 * \\
* \mathrm{p}<0.05\end{array}$ & $\begin{array}{c}3.23 \pm 0.10^{\#} \\
{ }^{*} p<0.05 \\
{ }^{\#} p<0.05\end{array}$ & $\begin{array}{c}2,61 \pm 0.06 \\
{ }^{*} p<0.05 \\
{ }^{\# \#} p<0.05 \\
{ }^{* *} p<0.05\end{array}$ \\
\hline $\lg M$ & $2.73 \pm 0.08$ & $\begin{array}{c}2.95 \pm 0.07 \text { \# } \\
{ }^{*} \mathrm{p}<0.05\end{array}$ & $\begin{array}{c}2.62 \pm 0.07^{\#} \\
{ }^{*} p<0.05 \\
{ }^{\#} p<0.05\end{array}$ & $\begin{array}{c}3.18 \pm 0.01^{\#} \\
{ }^{*} p<0.05 \\
{ }^{\# \#} p<0.05 \\
{ }^{* \star} p<0.05\end{array}$ \\
\hline $\lg A$ & $1.73 \pm 0.02$ & $\begin{array}{c}1.87 \pm 0.08 * \\
{ }^{*} \mathrm{p}<0.05\end{array}$ & $\begin{array}{c}1.13 \pm 0.099^{\#} \\
{ }^{*} p<0.05 \\
{ }^{\#} p<0.05\end{array}$ & $\begin{array}{c}0.98 \pm 0.09 \\
{ }^{*} p<0.05 \\
{ }^{\# \#} p<0.05 \\
* * p<0.05\end{array}$ \\
\hline
\end{tabular}

Notes: $1 .{ }^{\#}$ - the accuracy of the difference with respect to such indicators of a group of intact animals.

$2 .{ }^{*}$ - the reliability of the difference with respect to such indicators of the comparative group.

3. ${ }^{\#}$ - the reliability of the difference with respect to these indicators of a group of animals for 1 day of observation.

4. ${ }^{* *}$ - the accuracy of the difference with respect to such indicators of a group of animals for 3 days of observation. 
$\lg A-65 \%$ of the values of the groups of intact animals. By the $7^{\text {th }}$ day, the concentration of $\lg \mathrm{G}$ continued to decrease and amounted to $72 \%$ of the norm, respectively, Ig M increased to $116 \%$, and with $\lg \mathrm{A}$, it decreases even more, by $57 \%$ of the level of a healthy group of rats. It is worth noting that all the indicators were also significantly lower than similar indicators of groups of animals with acute peritonitis.

It should be noted that the level of immunoglobulins in the experimental animals from the AGP on the $C D$ for the first day of observation was statistically significantly lower comparing to the AGP groups: Ig $\mathrm{G}$ level was lower by $38 \%$, while Ig $\mathrm{M}$ and Ig A - by $16 \%$ and $21 \%$, respectively. A similar trend was observed on the third day from the moment of AGP modeling. Also, on the $7^{\text {th }}$ day of the experiment all classes of immunoglobulins were statistically significantly lower than the following indicators of a group of animals from the acute peritonitis: the level of Ig $\mathrm{G}$ was lower by $21 \%$, while $\lg \mathrm{M}$ and $\lg \mathrm{A}-$ by $17 \%$ and $56 \%$ respectively, which confirms the presence of secondary immunodeficiency.

It is known that $\lg G$ is a highly specific immunoglobulin, its concentration influences the effectiveness of the immune response and antiinfection protection, stimulates the favorable flow of the inflammatory process and its level must be increased for positive outcomes at least twice. Therefore, the low level of $\lg G$ in animals with AGP model on the background of diabetes is a direct sign of severe immune deficiency, a prerequisite for a complex outcome of the course of peritonitis and a clear immune criterion for negative prognosis the progress of peritonitis.

CONCLUSIONS. Animals with acute peritonitis on the background of diabetes mellitus had significantly damaged protective mechanisms of the humoral immune system, which was confirmed statistically significantlower levels of immunoglobulins of classes A, M, G comparing to a group of animals with a simulated acute peritonitis alone. Discovered functional insufficiency of the humoral link indicates significant weakening of the organism protection factors in acute peritonitis against infection in case of diabetes presence with the development of secondary immunodeficiency.

In the prospect of further research, it is planned to study the state of immune system when wetting the AGP on the background of the diabetes.
LITERATURE

1. Дзюбановський І. Я. Синдром поліорганної недостатності та його корекція у хворих на гострий поширений перитоніт / І. Я. Дзюбановський, Б. О. Мігенько // Укр. Журн. Хірургії. - 2009. - № 2. - С. 56-59.

2. Білик І. І. Гострий перитоніт як ускладнення гострого апендициту / І. І. Білик // Клініч. та експерим. патологія. - 2016. - № 1 (43). - С. 187-189.

3. Гринчук Ф.В.Патогенетичні, клінічні і тактичні особливості при перитоніті та поєднаній патології / Ф. В. Гринчук // Харк. хірург. шк. - 2014. - № 6 (44). C. 47-49.

4. Spirt M. J. Complicated intra-abdominal infections: a focus on appendicitis and diverticulitis / M. J. Spirt // Postgrad. Med. - 2010. - 122, No. 1. - P. 39-51.

5. Kimura W. Problems and therapeutic strategy for emergen cy operation of the abdomen in the aged / W. Kimura, M. Mizutani, A. Fuse // Nippon Ronen Igakkai Zasshi. - 2014. - 41, No. 6. - P. 660-665.

6. Blot S. Critical issues in the clinical management of complicated intraabdominal infections / S. Blot, J. J. De Waele // Drugs. - 2015. - No. 65 (12). - P. 1611-1620.

7. Gliclazide treatment lowers serum ICAM-1 levels in poorly controlled type 2 diabetic patients / N. Papanas, D. Tziakas, G. Chalikias [et al.] // Diabetes \& Metabolism. 2016. - No. 4 (32). - P. 344-349.

8. Associations of mortality and diabetes complications in patients with type 1 and type 2 diabetes /
M. Cusick, A. D. Meleth, E. Agrón [et al.] // Diabetes Care. - 2005. No. 3 (28). - P. 617-625.

9. Верба Р. І. Особливості імунного просрілю у крові щурів з гострим поширеним перитонітом на тлі гіпотиреозу / Р. І. Верба, І. М. Кліщ // Мед. та клініч. хімія. - 2017. - 19, № 4 (73). - С. 10-17.

10. Гресько М. М. Імунологічна реактивність у хворих на гострий перитоніт / М. М. Гресько, М. Д. Гресько // Art of Medicine. - 2018. - № 1 (12). C. $48-51$.

11. Al-Malki A. L. Oat attenuation of hyperglycemiainduced retinal oxidative stress and NF-kkB activation in streptozotocin-induced diabetic rats / A. L. Al-Malki // Hindawi Publishing Corporation Evidence-Based Complementary and Alternative Medicine. - 2013.

12. Экспериментальная модель распространенного калового перитонита / В. А. Лазаренко, В. А. Липатов, Ю. Ю. Блинков, Д. В. Скориков // Человек и его здоровье. - 2008. - № 4. - С. 128-132.

13. Верба Р. І. Синдром ендогенної інтоксикації щурів з гострим поширеним перитонітом на тлі мерказоліліндукованого гіпотиреозу / Р. І. Верба, І. М. Кліщ // Мед. та клініч. хімія. -2017. - 19, № 2 (71). - С. 12-18.

14. Mart Mannik. Antibody-agarose immunoadsorbents: Complete removal of classes of immunoglobulins from serum / Mart Mannik, David E. Stage // J. Immunology. - 1971. - No. 6 (106). - P. 1670-1672. 


\section{REFERENCES}

1. Dziubanovskyi, I.Ya., \& Mihenko, B.O. (2009). Syndrom poliorhannoi nedostatnosti ta yoho korektsiia u khvorykh na hostryi poshyrenyi perytonit [Multiple organ failure syndrome and its correction in patients with acute peritonitis]. Ukr. zhurn. khirurhii - Ukrainian Journal of Surgery, 2, 56-59 [in Ukrainian].

2. Bilyk, I.I. (2016). Hostryi perytonit yak uskladnennia hostroho apendytsytu [Acute peritonitis as a complication of acute appendicitis]. Klinichna ta eksperymentalna patolohiia - Clinical and Experimental Pathology, 1 (43), 187-189 [in Ukrainian].

3. Hrynchuk, F.V. (2014). Patohenetychni, klinichni i taktychni osoblyvosti pry perytoniti ta poiednanii patolohii [Pathogenetic, clinical and tactical features in peritonitis and combined pathology]. Kharkivska khirurhichna shkola - Kharkiv Surgical Scool, 6 (44), 47-49 [in Ukrainian].

4. Spirt, M.J. (2010). Complicated intra-abdominal infections: a focus on appendicitis and diverticulitis. Postgrad. Med., 122, 1, 39-51.

5. Kimura, W., Mizutani, M., \& Fuse, A. (2014). Problems and therapeutic strategy for emergency operation of the abdomen in the aged. Nippon Ronen Igakkai Zasshi, 41, 6, 660-665.

6. Blot, S., \& De Waele, J.J. (2015). Critical issues in the clinical management of complicated intraabdominal infections. Drugs, 65 (12), 1611-1620.

7. Papanas, N., Tziakas D., \& Chalikias, G. (2016). Gliclazide treatment lowers serum ICAM-1 levels in poorly controlled type 2 diabetic patients. Diabetes \& Metabolism, 32, 4, 344-349.

8. Cusick, M., Meleth, A.D., \& Agrón, E. (2005). Associations of mortality and diabetes complications in patients with type 1 and type 2 diabetes. Diabetes Care, 28, 3, 617-625.

9. Verba, R.I., \& Klishch, I.M. (2017). Osoblyvosti imunnoho profiliu u krovi shchuriv $z$ hostrym poshyrenym perytonitom na tli hipotyreozu. Medychna ta klinichna khimiia - Medical and Clinical Chemistry, 4, 19, 10-17 [in Ukrainian].

10. Hresko, M.M., \& Hresko, M.D. (2018). Imunolohichna reaktyvnist u khvorykh na hostryi perytonit [Immunological reactivity in patients with acute peritonitis]. Art of Medicine, 1, 12, 48-51 [in Ukrainian].

11. Al-Malki, A.L. (2013). Oat attenuation of hyperglycemia-induced retinal oxidative stress and NF-kkB activation in streptozotocin-induced diabetic rats. Hindawi Publishing Corporation Evidence-Based Complementary and Alternative Medicine.

12. Lazarenko, V.A., Lypatov, V.A., Blynkov, Yu.Yu., \& Skorykov, D.V. (2008). Eksperymentalnaya model rasprostranennogo kalovogo perytonita [Experimental model of common fecal peritonitis]. Chelovek $i$ ego zdorovye - Man and His Health, 4, 128-132 [in Russian].

13. Verba, R.I., \& Klishch, I.M. (2017). Syndrom endohennoi intoksykatsii v shchuriv iz hostrym poshyrenym perytonitom na tli merkazolil indukovanoho hipotyreozu [Endogenous intoxication syndrome of rats with acute widespread peritonitis against a background of merkazolylinduced hypothyroidism]. Medychna ta klinichna khimiia - Medical and Clinical Chemistry, 2, 19, 12-18 [in Ukrainian].

14. Mart Mannik, David E. Stage (1971). Antibodyagarose immunoadsorbents: Complete removal of classes of immunoglobulins from serum. J. Immunology, 6, 106, 1670-1672.

І. Я. Дзюбановський ${ }^{1}$, Б. М. Вервега ${ }^{2}$, С. Р. Підручна ${ }^{1}$, Н. А. Мельник ${ }^{1}$, А. М. Продан ${ }^{1}$ ТЕРНОПІЛЬСЬКИЙ ДЕРЖАВНИЙ МЕДИЧНИЙ УНІВЕРСИТЕТ ІМЕНІ І. Я. ГОРБАЧЕВСЬКОГО ЛЬВІВСЬКИЙ НАЦІОНАЛЬНИЙ МЕДИЧНИЙ УНІВЕРСИТЕТ ІМЕНІ ДАНИЛА ГАЛИЦЬКОГО

\section{СТАН ГУМОРАЛЬНОЇ ЛАНКИ ІМУНІТЕТУ ПРИ ЕКСПЕРИМЕНТАЛЬНОМУ ПЕРИТОНІТІ НА ТЛІ ЦУКРОВОГО ДІАБЕТУ}

\section{Резюме}

Вступ. Поєднаний перебіг гострого перитоніту та цукрового діабету все частіше призводить до розвитку вторинних імунодефріцитних станів, що сприяє збільшенню відсотка післяопераційних ускладнень і летальних випадків, виникненню складності лікування та діагностики.

Мета дослідження - вивчити особливості гуморальної ланки імунної відповіді в організмі піддослідних тварин при змодельованому гострому поширеному перитоніті на тлі цукрового діабету порівняно зі щурами з експериментальним гострим перитонітом.

Методи дослідження. У роботі використовували 56 білих щурів. Цукровий діабет моделювали шляхом внутрішньоочеревинного введення стрептозотоцину фірми "Sigmal" з розрахунку 7 мг на 100 г маси тіла щура, гострий поширений перитоніт - введення 0,5 мл 10 \% профрільтрованої калової суспензії в черевну порожнину досліджуваних тварин. Визначали концентрацію імуноглобулінів (Ig) у сироватці крові. Терміни спостереження - 1-ша, 3-тя, 7-ма доби від початку моделювання перитоніту.

Результати й обговорення. Аналізуючи результати досліджень, можна констатувати, що спостерігались різноспрямовані зміни концентрації імуноглобулінів у сироватці крові щурів різних груп. Так, на 
1-шу добу після моделювання гострого поширеного перитоніту на тлі цукрового діабету рівень Ig G зменшився в 1,5 раза, Ig M - в 1,3 раза ma Ig A - в 1,4 раза (p<0,05). На 7-му добу експерименту всі класи імуноглобулінів були статистично значимо нижчими від таких показників групи тварин із гострим поширеним перитонітом: рівень Ig G - на 21 \%, a Ig M ma Ig A - на 17 і 56 \% відповідно ( $p<0,05)$. Результати наших досліджень свідчать про те, що наявність цукрового діабету при гострому поширеному перитоніті призводить до зниження резистентності гуморальної ланки імунної системи при антигенній стимуляції та до виникнення вторинних імунодефріцитних станів.

Висновки. У тварин із гострим перитонітом на тлі цукрового діабету суттєво знижуються захисні механізми гуморальної ланки імунітету, що підтверджується статистично значимо нижчими рівнями імуноглобулінів класів A, M, G порівняно з групою щурів із змодельованим гострим перитонітом. Виявлена функціональна недостатність гуморальної ланки імунітету вказує на значне послаблення фракторів захисту організму при гострому перитоніті на тлі цукрового діабету з розвитком вторинного імунодефіцumy.

КЛЮЧОВІ СЛОВА: гострий перитоніт; цукровий діабет; гуморальний імунітет; імуноглобуліни.

И. Я. Дзюбановский ${ }^{1}$, Б. М. Вервега ${ }^{2}$, С. Р. Пидручная ${ }^{1}$, Н. А. Мельник ${ }^{2}$, А. М. Продан ${ }^{1}$ ТЕРНОПОЛЬСКИЙ ГОСУДАРСТВЕННЫЙ МЕДИЦИНСКИЙ УНИВЕРСИТЕТ ИМЕНИ И. Я. ГОРБАЧЕВСКОГО ЛЬВОВСКИЙ НАЦИОНАЛЬНЫЙ МЕДИЦИНСКИЙ УНИВЕРСИТЕТ ИМЕНИ ДАНИЛА ГАЛИЦКОГО

\section{СОСТОЯНИЕ ГУМОРАЛЬНОГО ЗВЕНА ИММУНИТЕТА ПРИ ЭКСПЕРИМЕНТАЛЬНОМ ПЕРИТОНИТЕ НА ФОНЕ САХАРНОГО ДИАБЕТА}

\section{Резюме}

Вступление. Совместное течение острого перитонита и сахарного диабета все чаще приводит $к$ развитию вторичных иммунодефицитных состояний, что способствует увеличению процента послеоперационных осложнений и летальных исходов, возникновению сложности лечения и диагностики.

Цель исследования - изучить особенности гуморального звена иммунного ответа в организме подопытных животных при смоделированном остром распространенном перитоните на фроне сахарного диабета по сравнению с крысами с экспериментальным острым перитонитом.

Методы исследования. В работе использовали 56 белых крыс. Сахарный диабет моделировали путем внутрибрюшинного введения стрептозотоцина фрирмы "Sigmal" из расчета 7 мг на 100 г массы тела крысы, острый распространенный перитонит - введения 0,5 мл 10 \% профильтрованной каловой суспензии в брюшную полость исследуемых животных. Определяли концентрацию иммуноглобулинов (Ig) в сыворотке крови. Сроки наблюдения - 1-е, 3-и, 7-е сутки от начала моделирования перитонита.

Результаты и обсуждение. Анализируя результаты исследований, можно констатировать, что наблюдались разнонаправленные изменения концентрации иммуноглобулинов в сыворотке крови крыс разных групп. Так, на 1-е сутки после моделирования острого распространенного перитонита на фроне сахарного диабета уровень Ig $G$ уменьшился в 1,5 раза, Ig M - в 1,3 раза u Ig A - в 1,4 раза (p<0,05). Ha 7-e сутки эксперимента все классы иммуноглобулинов были статистически значимо ниже таких показателей группы животных с острым распространенным перитонитом: уровень $\lg \mathrm{G}$ - на $21 \%$, a $\lg \mathrm{M}$ u $\lg \mathrm{A}-$ на 17 и 56 \% соответственно (p<0,05). Результаты наших исследований свидетельствуют о том, что наличие сахарного диабета при остром распространенном перитоните приводит к снижению резистентности гуморального звена иммунной системы при антигенной стимуляции и к возникновению вторичных иммунодефицитных состояний.

Выводы. У животных с острым перитонитом на фроне сахарного диабета существенно снижаются защитные механизмы гуморального звена иммунитета, что подтверждается статистически значимо более низкими уровнями иммуноглобулинов классов $A, M, G$ по сравнению с группой крыс со смоделированным острым перитонитом. Обнаруженная фрункциональная недостаточность гуморального звена иммунитета указывает на значительное ослабление фракторов защиты организма при остром перитоните на фроне сахарного диабета с развитием вторичного иммунодефицита.

КЛЮЧЕВЫЕ СЛОВА: острый перитонит; сахарный диабет; гуморальный иммунитет; иммуноглобулины.

Received 31.01.19

Address for correspondence: B. M. Vervega, Sokolyna Street 23, Lviv, 79038, Ukraine, e-mail: danaverveha@gmail.com. 